\title{
Comparative Study on the Migration of Heavy Metals in the Sewage Sludge Treated by Supercritical/Subcritical Water Oxidation Process
}

\author{
Rui MA ${ }^{1, a}$, Yang $\mathrm{ZHOU}^{1, \mathrm{~b}}$ and Lin $\mathrm{FANG}^{1, \mathrm{c},{ }^{*}}$ \\ ${ }^{1}$ College of Chemical and Enviornmental Engineering, Shenzhen University, Shenzhen, China \\ amarui067@163.com, byangzhou0724@126.com, cfanglinhit@163.com \\ ${ }^{*}$ Corresponding author: Lin FANG
}

\begin{abstract}
Keywords: supercritical water oxidation, subcritical water oxidation, secondary sludge, migration law of heavy metals.

Abstract. Super/sub-critical water oxidation technology has been utilized to treat sewage sludge in the study. Heavy metal content and characteristics of leaching toxicity in the reaction effluent have been investigated in detail, and then the relationship between the microstructure of sludge residue and immobilization of heavy metals is analyzed systematically. The obtained results show that the enrichment ratios of heavy metals in the sludge residue are above 68\%, except As; Super/sub-critical water oxidation process has good immobilization effects on the heavy metals in sewage sludge residue, except $\mathrm{Cd}$ and $\mathrm{Cu}$; Compared with subcritical state, supercritical water oxidation process has more obvious immobilization effects on the heavy metals in sewage sludge residue. The heavy metals in sewage sludge residue exist in the form of complex compounds, presenting obviou s crystalline state, with part of crystal structures being similar. The formation of crystal microstructures contribute to the enrichment and immobilization of heavy metals in sewage sludge.
\end{abstract}

\section{Introduction}

The heavy metals in sewage sludge generally are the important factors that limits their utilization, among which, the pollutant heavy metals such as $\mathrm{Cu}, \mathrm{Pb}, \mathrm{Zn}, \mathrm{Ni}, \mathrm{Cr}, \mathrm{Hg}$ and $\mathrm{Cd}$ attract extensive attention in the treatment and disposal process of sewage sludge ${ }^{[1]}$. Researches show that the heavy metals in sewage sludge mainly exist in the form of inorganic precipitators and organic complex such as oxide, hydroxide, silicate and insoluble salts ${ }^{[2,3]}$. If the sewage sludge is directly used for landfill or agricultural utilization, it's bound to generate pollution to the soil and surface water, which has hidden dangers to serious sanitation and environmental pollution. Super/sub-critical water oxidation method is a new technology that can effectively decompose the non-degradable organic matters in sewage sludge and has attracted wide research in the environmental field by the scholars. Researches on supercritical water oxidation method for sewage sludge are more on analyzing the characteristics and laws of organic matter degradation ${ }^{[4,5]}$, while the researches on the migration and conversion laws of heavy metals in sewage sludge treated by supercritical water oxidation method are rarely reported. 


\section{Experiment materials and methods}

Experiment materials. The Physical and Chemical Characteristics of Sewage Sludge are shown in Table 1.

Table 1 The Physical and Chemical Characteristics of Sewage Sludge

\begin{tabular}{ccc}
\hline Item & Range & Average Value \\
\hline water ratio $(\%)$ & $93.59-97.25$ & 95.67 \\
solids content $(\%)$ & $6.41-2.75$ & 4.33 \\
organic matter content $(\%)$ & $68.73-70.83$ & 69.78 \\
inorganic matter content $(\%)$ & $31.27-29.17$ & 30.22 \\
$\mathrm{As}(\mathrm{mg} / \mathrm{kg})$ & $6.985-8.084$ & 7.384 \\
$\mathrm{Cd}(\mathrm{mg} / \mathrm{kg})$ & $0.525-1.984$ & 1.516 \\
$\mathrm{Cr}(\mathrm{mg} / \mathrm{kg})$ & $74.231-76.149$ & 75.312 \\
$\mathrm{Cu}(\mathrm{mg} / \mathrm{kg})$ & $998.874-1002.001$ & 1000.396 \\
$\mathrm{~Pb}(\mathrm{mg} / \mathrm{kg})$ & $317.998-320.124$ & 319.057 \\
$\mathrm{Zn}(\mathrm{mg} / \mathrm{kg})$ & $2753.296-2759.265$ & 2754.916 \\
\hline
\end{tabular}

Experiment devices. Super/sub-critical water oxidation for sewage sludge is conducted in the devices shown in Fig. 1, of which, the reaction kettle has volume of $300 \mathrm{~mL}$, the maximum design pressure is at $32 \mathrm{MPa}$ and temperature at $525^{\circ} \mathrm{C}$, the pressure and temperature are respectively measured by means of the pressure gauge and thermocouple in the intelligent control cabinet. The pressure inside the reaction kettle is controlled by means of the water input and temperature heated in the reaction kettle.

The experiment uses $100 \mathrm{~mL}$ secondary sludge, taking $\mathrm{H}_{2} \mathrm{O}_{2}$ of mass fraction $30 \%$ as oxidant. Before the experiment, put sewage sludge into the high-pressure reaction kettle, and embed the reaction kettle with heating mantle; we use $100 \mathrm{~mL}$ min Nitrogen to purge the whole system, lose all the valves after $5 \mathrm{~min}$, and cool the reaction system by pumping in tap water. Under supercritical water oxidation, set temperature above $374^{\circ} \mathrm{C}$ and pressure above $22 \mathrm{Mpa}$, turn on the power switch of heater and begin to heat. When the experiment temperature and pressure for supercritical water oxidation reach the set values, open $b$ valve, input a certain amount of $\mathrm{H}_{2} \mathrm{O}_{2}$ into reaction kettle through high pressure liquid pump, open $\mathrm{g}$ and $\mathrm{f}$ valves with the detention time reached, and collect the liquid samples for measurement. Unload the heating mantle, continue to input cooling water, open all switches when the temperature inside reaction kettle decreases to $80^{\circ} \mathrm{C}$. Open reaction kettle and take out of sewage sludge samples for measurement. Under subcritical water oxidation, operate as above by setting the temperature of the reaction device less than $370^{\circ} \mathrm{C}$ and pressure less than $10 \mathrm{MPa}$.

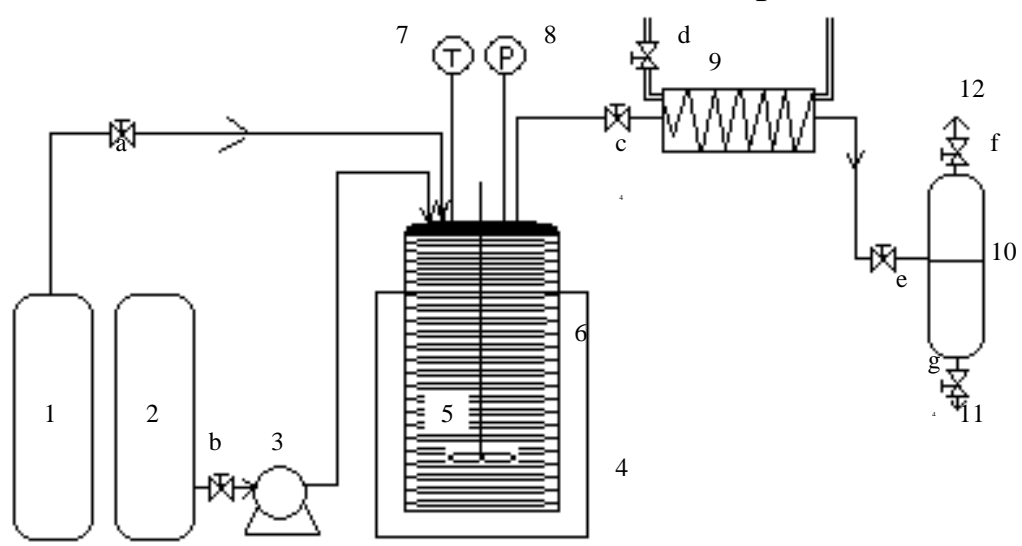

1. nitrogen cylinder 2 . hydrogen peroxide cylinder 3 . high pressure liquid pump

4. heater 5. Stirrer 6. reaction kettle 7. temperature controller

8. pressure gauge 9. Condenser 10. Separator

11. liquid product 12 . gaseous product

Fig. 1 Experiment Device Diagram 
Microwave digestion ${ }^{[6]}$. Put samples with proper amount into $200 \mathrm{~mL}$ beaker, seal up the mouth of beaker with tinfoil, put the samples into $-4^{\circ} \mathrm{C}$ refrigerator for pre-freezing, take them out after 18 hours and then put them into freezer dryer to dry for 48 hours. Grind the samples after freeze-drying throughout 100 mess sieves, take pretreated $0.1000 \mathrm{~g}$ samples and put the samples into microwave digestion tank, add $5 \mathrm{~mL} \mathrm{HNO}_{3}, 1.0 \mathrm{~mL} \mathrm{HF}$ and $2.0 \mathrm{~mL} \mathrm{H}_{2} \mathrm{O}_{2}$ respectively, place there for $30 \mathrm{~min}$, and then put the microwave digestion tank into microwave digestion instrument(ETHOS ONE), conduct microwave digestion as per set procedures.

The experiment of leaching toxicity in sewage sludge residue and the measurement of heavy metals content $^{[7]}$. This paper has produced extractable liquor from sewage sludge residue by means of Solid Waste-Extraction Procedure for Leaching Toxicity-Horizontal Vibration Method (HJ557-2010). This paper measures heavy metal content in different samples by means of ICP-MS, among which, the enrichment degree of heavy metals is calculated as per the following Eq. 1:

$$
\text { metals }=\frac{\text { heavy metals }{ }^{\prime} \text { concentration in sewage sludge }}{\text { heavy metals }{ }^{\prime} \text { concentration in raw sludge }} \text {. }
$$

\section{Experiment Results}

Changing laws of reaction effluent and heavy metals' content in sewage sludge residue. The total amounts of heavy metals' content in reaction effluent that are treated by means of super/sub-critical water oxidation method are shown in Table 2. Except $\mathrm{Cu}$, compared with subcritical state, the concentrations of other heavy metals in effluent under SCWO condition are higher than that under subcritical water oxidation condition, and the concentration of $\mathrm{Cr}$ under supercritical water oxidation condition is $88.63 \%$ higher than that under subcritical water oxidation condition. The effluent concentration of $\mathrm{Cu}$ under subcritical water oxidation condition is $52.94 \%$ higher than that under supercritical water oxidation condition.

Table 2 Contents of Heavy Metals in Reaction Effluent

\begin{tabular}{cccc}
\hline & \multirow{2}{*}{$\begin{array}{c}\text { raw sewage } \\
\text { sludge } \\
\text { element }\end{array}$} & \multicolumn{2}{c}{ effluent $(\mathrm{mg} / \mathrm{kg})$} \\
\cline { 3 - 4 } & 7.384 & subcritical & supercritical \\
\hline $\mathrm{As}$ & 1.516 & 0.003 & 0.019 \\
$\mathrm{Cd}$ & 75.312 & 0.003 & 0.006 \\
$\mathrm{Cr}$ & 1000.396 & 0.285 & 2.507 \\
$\mathrm{Cu}$ & 319.057 & 0.442 & 0.208 \\
$\mathrm{~Pb}$ & 2754.916 & 0.086 & 0.092 \\
$\mathrm{Zn}$ & & 0.870 & 0.904 \\
\hline
\end{tabular}

The total amounts of heavy metals' content in residue treated by means of super/sub-critical water oxidation method are shown in Table 3. As seen from Table 3, As seen from Table 2, super/sub-critical water oxidation for secondary sludge renders heavy metals obviously enriched in residue, and the enrichment ratios in residue range stay between 55\% and 97\%. Except As and Cr, compared with subcritical state, heavy metals are easier to enrich in sewage sludge under supercritical state, of which, the enrichment ratio of Cd in sewage sludge residue treated by SCWO process is $14.91 \%$ higher than that by subcritical water oxidation process. 
Table 3 Contents of Heavy Metals in Sewage Sludge Residue

\begin{tabular}{|c|c|c|c|c|}
\hline \multirow{3}{*}{ element } & \multicolumn{4}{|l|}{ residue } \\
\hline & \multicolumn{2}{|c|}{ element content $(\mathrm{mg} / \mathrm{kg})$} & \multicolumn{2}{|c|}{ enrichment rate of heavy metals $(\%)$} \\
\hline & subcritical & supercritical & Subcritical & Supercritical \\
\hline As & 7.088 & 4.120 & $95.99 \%$ & $55.80 \%$ \\
\hline $\mathrm{Cd}$ & 1.031 & 1.257 & $68.01 \%$ & $82.92 \%$ \\
\hline $\mathrm{Cr}$ & 72.062 & 68.159 & $95.68 \%$ & $90.50 \%$ \\
\hline $\mathrm{Cu}$ & 954.67 & 968.643 & $95.43 \%$ & $96.83 \%$ \\
\hline $\mathrm{Pb}$ & 241.980 & 281.296 & $75.84 \%$ & $88.16 \%$ \\
\hline $\mathrm{Zn}$ & 2514.726 & 2662.732 & $91.28 \%$ & $96.65 \%$ \\
\hline
\end{tabular}

Analysis of leaching toxicity of heavy metals in sewage sludge residue. The experiment results of the leaching toxicity of residue after SCWO treatment for sewage sludge are shown in Table 4. As seen from Table 3, except $\mathrm{Cd}$ and $\mathrm{Cu}$, compared with subcritical state, supercritical state has better immobilization effects on other heavy metals in residue, of which, the leaching concentration of As decreases by $83.33 \%$. The leaching concentrations of $\mathrm{Cd}$ and $\mathrm{Cu}$, after subcritical treatment, decrease by $50.00 \%$ and $3.99 \%$ respectively compared with supercritical state. Based on the above analysis, supercritical state has better immobilization effects on other heavy metals in residue than subcritical state.

Table 4 Experiment results of the leaching toxicity of heavy metals

\begin{tabular}{l|llllll}
\hline $\begin{array}{l}\text { heavy metals } \\
\text { leaching }\end{array}$ & As & $\mathrm{Cd}$ & $\mathrm{Pb}$ & $\mathrm{Cr}$ & $\mathrm{Cu}$ & $\mathrm{Zn}$ \\
\cline { 1 - 5 } concentration (ug/mL) & & & & & & \\
\hline supercritical & 0.01 & 0.04 & 0.09 & 2.59 & 19.07 & 0.47 \\
subcritical & 0.06 & 0.02 & 0.09 & 2.67 & 18.31 & 0.64 \\
comparative analysis (\%) & $83.33 \%$ & $-50.00 \%$ & $0.00 \%$ & $3.00 \%$ & $-4.15 \%$ & $26.5 \%$ \\
\hline
\end{tabular}

XRD analysis of sewage sludge residue. The XRD analysis of raw sewage sludge and the sewage sludge residue after super/sub-critical water oxidation process is shown in Fig. 2. As seen from Fig. 2, there exist crystalline compounds such as $\mathrm{SiO}_{2}, \mathrm{CuCl}_{2}, \mathrm{~Pb}_{2} \mathrm{O}_{3}, \mathrm{Cu}_{2} \mathrm{Se}, \mathrm{Bi}_{3} \mathrm{CrWO}_{12}$ and $\mathrm{CaF}_{2}$ in raw sewage sludge, and crystalline compounds such as $\mathrm{PbZnSiO}$, $\mathrm{LiBr},\left(\mathrm{NH}_{4}\right) \mathrm{CO}_{2}(\mathrm{OH}), \mathrm{Fe}_{3}\left(\mathrm{PO}_{4}\right)_{2}, \mathrm{~Pb}_{2} \mathrm{O}_{3}$ and $\mathrm{CaCuO}_{2}$ appear in sewage sludge residue after supercritical treatment, crystalline compounds such as $\mathrm{SiO}_{2}, \mathrm{ZnAl}_{2} \mathrm{Se}_{4}, \mathrm{Cu}_{5} \mathrm{FeS}_{4}, \mathrm{AlP}, \mathrm{GaP}, \mathrm{CaF}_{2}$ and $\mathrm{C}_{10} \mathrm{H}_{12} \mathrm{Cr}_{2} \mathrm{~N}_{2} \mathrm{O}_{7}$ appear in sewage sludge residue after subcritical treatment. Comparing the sewage sludge residue after super/sub-critical treatment with raw sewage sludge, the crystalline phenomenon of the heavy metals increase obviously, and especially obvious at $20^{\circ}$ to $35^{\circ}$, thus it shows that: the heavy metals in sewage sludge residue after super/sub-critical treatment exist in the form of complex compounds, and part of crystal structures are similar. The $\mathrm{Cd}, \mathrm{Pb}, \mathrm{Cu}, \mathrm{Zn}$ and $\mathrm{Cr}$ in the heavy metals of this paper have high enrichment degree in residue. In addition, the element of As, with low boiling point, volatile and gasification features has obviously decreasing content in the residue, compared with that in raw sewage sludge, which is because, during the reaction process, the element of As with low boiling point in sewage sludge is gasified by high temperature. Based on the above analysis, the effective enrichment of heavy metals in sewage sludge residue is closely related to the physical structures of heavy metal crystal and the existing condition of heavy metals under high temperature and high pressure. 


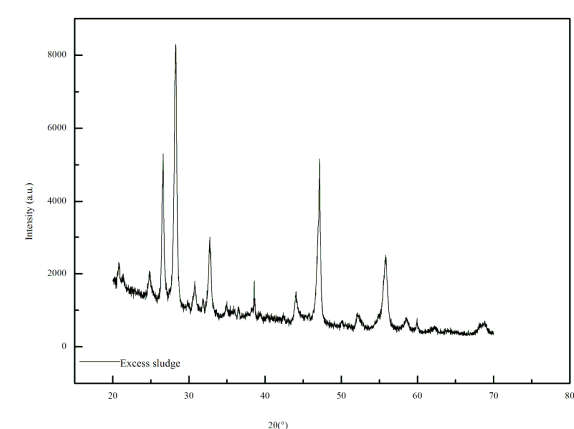

(a) raw sewage sludge

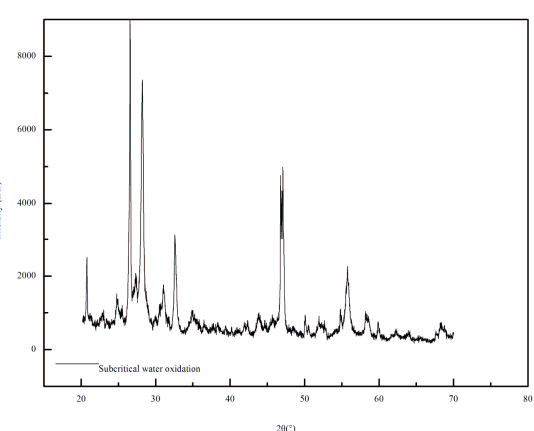

(b) subcritical

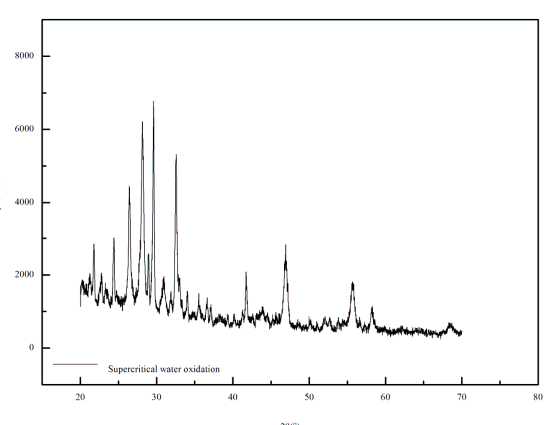

(c) supercritical

Fig. 2 XRD Diagram of Sewage Sludge under Different Conditions

SEM-EDX analysis. The micromorphologies of raw sewage sludge and the sewage sludge residue after super/sub-critical water oxidation treatment are shown in Fig. 3, and the analysis of energy spectra in Fig. 3. As seen from SEM images, the cell walls of raw sewage sludge are complete with large holes; the fine particles increase in the sewage sludge residue after subcritical treatment, and part of fine particles begin to gather, the edge angles become vague and coking appears; edges appear in the fine particles of the sewage sludge residue after supercritical treatment, and the coking becomes more obvious, the coking surface becomes smooth and dense, and the fine particles disappear gradually, and thus forming elliptical crystal structure. As seen from the analysis, the super/sub-critical treatment renders sewage sludge residue easier to form crystal, of which, the crystals of sewage sludge residue after supercritical treatment are more obvious.

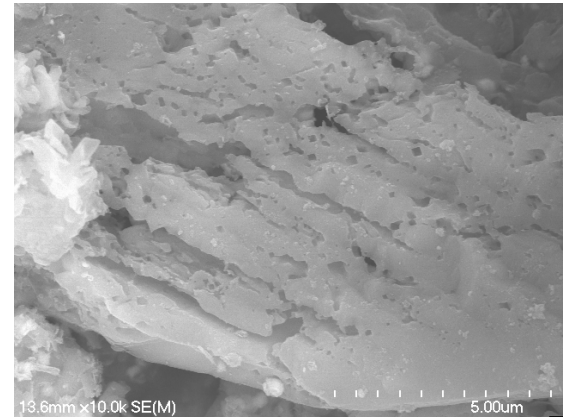

(a) raw sewage sludge

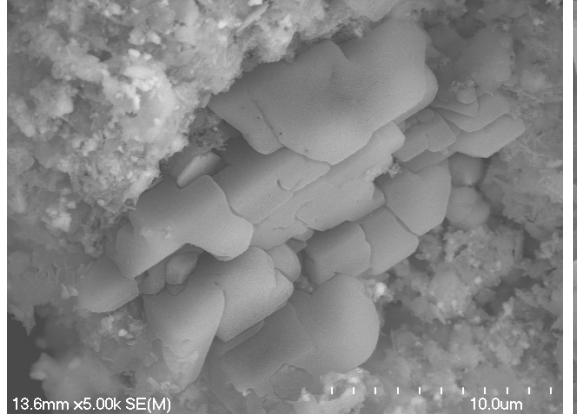

(b) subcritical

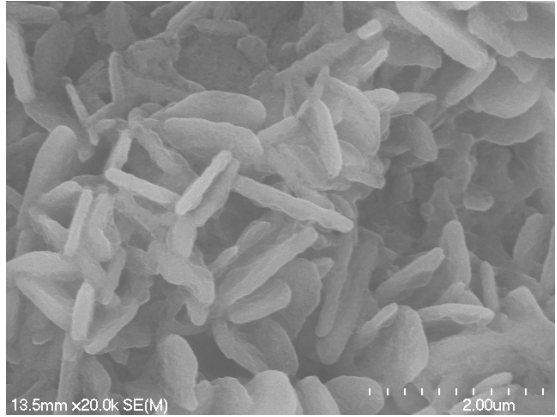

(c) supercritical

Fig. 3 SEM Images of Sewage Sludge under Different Conditions

As seen from EDX analysis, the elements of untreated secondary sludge are mainly $\mathrm{O}, \mathrm{Si}$ and $\mathrm{Al}$, with the mass ratios of $29.46 \%, 9.23 \%$ and $5.88 \%$ respectively; the elements of the sewage sludge residue after subcritical treatment are mainly $\mathrm{O}, \mathrm{Si}$ and $\mathrm{Al}$, with the mass ratios of $34.08 \%, 7.61 \%$ and $7.38 \%$ respectively; the elements of the sewage sludge residue after supercritical treatment are mainly $\mathrm{O}, \mathrm{Si}, \mathrm{Al}, \mathrm{Fe}, \mathrm{P}, \mathrm{S}$ and $\mathrm{Ca}$, with the mass ratios of $26.58 \%, 6.84 \%, 7.55 \%, 14.28 \%, 3.44 \%, 3.35 \%$ and $4.89 \%$ respectively.

It can be further analyzed from Fig. 4, that, comparing with raw sewage sludge and the sewage sludge residue after subcritical treatment, the content of element $\mathrm{C}$ in sewage sludge residue after supercritical treatment decreases obviously, showing that the decomposition of organic matters in sewage sludge residue is more thorough. Meanwhile, $\mathrm{Fe}, \mathrm{Al}$ and $\mathrm{Ca}$ in sewage sludge residue after supercritical treatment can generate phosphate, aluminum phosphate and calcium phosphate with phosphorus, thus realizing the role of stabilizing the heavy metal ions ${ }^{[8,9]}$. 

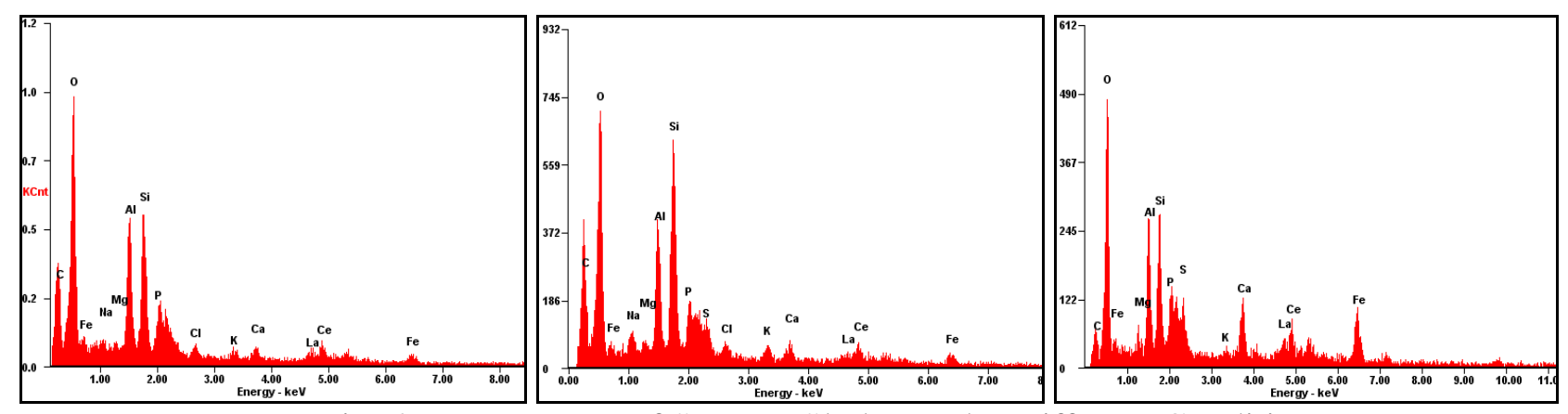

Fig. 4 EDX Images of Sewage Sludge under Different Conditions

\section{Summary}

(1) Super/sub-critical water oxidation treatment for secondary sludge renders the heavy metals enriched obviously in residue, except As (with enrichment ratio in residue of 68\%), the enrichment ratios of other heavy metals in residue are above 55.8\%. Except As and $\mathrm{Cr}$, compared with subcritical state, heavy metals are easier to enrich in sewage sludge under supercritical state.

(2) Super/sub-critical water oxidation process has good immobilization effects on the heavy metals in sewage sludge residue. Except $\mathrm{Cd}$ and $\mathrm{Cu}$, compared with subcritical state, supercritical water oxidation process has more obvious immobilization effects on the heavy metals in sewage sludge residue.

(3) The heavy metals in sewage sludge residue after super/sub-critical water oxidation The effective enrichment of heavy metals in sewage sludge residue is closely related to the physical structures of heavy metal crystal and the existing condition of heavy metals under high temperature and high pressure.

\section{Acknowledgements}

This research was financially supported by the Integration of Industry, Education and Research of Guangdong Province (2012B091100197) and Science and Technology Program of Shenzhen of China (JCYJ20140418091413583).

\section{References}

[1] R.P. Singh, M. Agrawal, Variations in heavy metal accumulation, growth and yield of rice plants grown at different sewage sludge amendment rates, Ecotoxicol. Environ. Saf. 73(2010) 632-641.

[2] G.Q. Peng, G.M. Tian, J.Z. Liu, Q.B. Bao and L. Zang, Removal of heavy metals from sewage sludge with a combination of bioleaching and electrokinetic remediation technology, Desalination. 271(2011)100-104.

[3] A. Pathak, M.G. Dastidar, T.R. Sreekrishnan, Bioleaching of heavy metals from sewage sludge: a review, J. Environ. manage. 90(2009) 2343-2353.

[4] W. Rulkens, Sewage sludge as a biomass resource for the production of energy: overview and assessment of the various options, Energy \& Fuels. 22(2007) 9-15.

[5] J.L. Zhang, J.G. Liu, C. Li, et al., Comparison of the fixation effects of heavy metals by cement rotary kiln co-processing and cement based solidification/stabilization, J. Hazard. Mater. 165(2009)1179-1185.

[6] H.M. Kuss, Applications of microwave digestion technique for elemental analyses, Fresenius. J. Anal. Chem.343(1992)788-793.

[7] I. Mantis, D. Voutsa, C. Samara. Assessment of the environmental hazard from municipal and industrial wastI.ewater treatment sludge by employing chemical and biological methods, Ecotoxicol. Environ. Saf. 62(2005)397-407. 
[8] J. Jin, Q. Wang, H. Li, et al., Distribution and Leaching Characteristics of Heavy Metals in MSWI Fly Ash, Environ. Sci. Technol. 4(2007)1-3.

[9] I.H. Hwang, Y. Ouchi, T. Masuto, Characteristics of leachate from pyrolysis residue of sewage sludge, Chemosphere. 68(2007)1913-1919. 